\title{
Research of relationship of functional-role positions (ego-states) with indicators of future specialists' independence
}

\section{Дослідження взаємозв'язку функціонально-рольових позицій (его-станів) 3 показниками самостійності майбутніх фахівців}

Received: March 30, 2021

\begin{abstract}
The purpose of empirical research is to establish the relationship of functional-role positions (egostates) with other indicators of future professionals 'independence to establish the level of manifestation of functional ego-states. The investigation contemplated methods are projective methods, psychodiagnostic methods with valid scales, author's method "Indirect selfassessment of independence" ("ISI") and the author's questionnaire "Persuasion in independence" ("PII"). The results indicated that the most important for the respondents the value of independence, the more they are focused on taking into account the actual possibilities and autonomous action on the basis of objective data (ego-state "Adult"), as well as control, management, criticism of other people (ego-state "Parent-controller"). Therefore, the more autonomous respondents, the less interdependent they are, and vice versa.
\end{abstract}

Key words: psychological boundary, codependence, motivation, autonomy, management psychology.
Accepted: May 20, 2021

Written by:

Ihor Popovych ${ }^{22}$

https://orcid.org/0000-0002-1663-111X

Mariia Pavliuk $^{23}$

https://orcid.org/0000-0002-0822-8128

Nelya Sirant ${ }^{24}$

https://orcid.org/0000-0002-8075-1511

Igor Zhigarenko $^{25}$

https://orcid.org/0000-0001-5851-9137

Oksana Serhieienkova ${ }^{26}$

https://orcid.org/0000-0002-1380-7773

\section{Анотація}

Метою емпіричного дослідження $\epsilon$ встановлення взаємозв'язку функціональнорольових позицій (его-станів) 3 іншими показниками незалежності майбутніх фахівців для встановлення рівня прояву функціональних его-станів. Методами дослідження $€$ передбачувані проекти, психодіагностичні методи 3 дійсними шкалами, авторський метод «Непряма самооцінка незалежності» («ISI») та авторський опитувальник «Переконання у незалежності» («РІІ»). Результати показали, що найбільш важливим для респондентів $€$ цінність незалежності, тим більше вони зосереджені на врахуванні реальних можливостей та автономних дій на основі об’єктивних даних (его-стан “Дорослий”), а також контроль, управління, критика інших людей (его-держава “Батько-контролер”). Тому чим автономніші респонденти, тим вони менш взаємозалежні, і навпаки.

Ключові слова: психологічна межа, співзалежність, мотивація, автономність, психологія управління.

\footnotetext{
${ }^{22}$ Doctor of Psychological Sciences, Full Professor of the Department of Psychology, Kherson State University, Kherson, Ukraine.

${ }^{23}$ Doctor of Psychological Sciences, Professor of the Department of Psychology, Interregional Academy of Personnel Management, Kyiv, Ukraine.

${ }^{24}$ Candidate of Pedagogical Sciences, Associate Professor of the Department of Primary and Preschool Education, Ivan Franko National University of Lviv, Lviv, Ukraine.

${ }^{25}$ Doctor of Psychological Sciences, Associate Professor of Department Psychology and Sociology, Volodymyr Dahl East Ukrainian National University, Severodonetsk, Ukraine.

${ }^{26}$ Doctor of Psychological Sciences, Head of Psychology of Personality and Social Practices Department, Institute of Human Sciences, Borys Grinchenko Kyiv University, Kyiv, Ukraine.
} 


\section{Introduction}

Taking into account the latest trends in the integration of existing psychological theories and practices, the relevance of the research of the relationship of functional-role positions (egostates) with indicators of future professionals' independence has no doubt. There is a change of competing or ignoring style between theories, areas, schools to an integrative scientific and practical worldview. The emphasis in modern research is on the interactions and relationships in the study of various areas of a person's life. The field of professional training of the future specialist is not an exception. There are more and more approaches today that see the individual as the architect of one's own way of life. Under such conditions, the study of the psychology of the development of the future specialist's independence is especially in demand.

We assume that the research of the relationship of functional-role positions and the construction of a holistic structure of independence of the future specialist will allow to obtain significant empirical results, which will promote an objective understanding of the mechanisms of independence's formation in the period of professional development; the implementation of the received knowledge will be essential in the construction of purposeful psychological influences on the development of personality independence in adulthood.

The purpose of empirical research is to establish the relationship of functional-role positions (egostates) with indicators of independence of future specialists during professional training.

\section{Literature review}

A number of works on pedagogy and psychology of personality development at different stages of ontogenesis are devoted to the study of independence. Independence is considered as one of the leading qualities of personality, which is demonstrated in the ability to determine the goal, to persevere to achieve it "by one's own efforts, to treat one's activity responsibly, to act consciously and proactively, not only in the usual, but also in new conditions that require non-standard decisions (Halian, 2019; Passov, 2002).

Understanding the mechanisms of independence is associated with the development of the provision that the individual develops and is formed in the activity, therefore, independence is considered at different ages in the context of the activity.

S. Rubinstein (2007), for example, drew attention to the fact that the first stage in the real formation of personality as an independent subject is associated with the mastery of one's own body, with the emergence of arbitrary movements that are formed in the process of the first objective actions. The next step on this ground is the beginning of walking, independent movement. What is more important here than the technique of movement, is the change in the relationship of the individual with others, which affects the possibility of independent movement, as well as independent mastery of the subject. This creates some independence of the child in relation to other people. The individual realizes his independence, himself as an independent subject only through his relationship with others (Rubinstein, 2007).

Independence stems from the fundamental abilities of man to self-distancing and selftranscendence, i. e. going beyond himself. The behavior of the individual is determined by the values and meanings through which the individual can determine their own attitude to events. Awareness of the dominant type of psychological boundaries and the etiology of their origin will allow to intensify the effectiveness of the "true self" and mobilize intrapersonal resources for the development of independence.

Research on the psychology of early development confirms the importance of the early stages of independence. The ability to initiate the process of separation and to engage in various kinds of autonomous activity is associated with the development of language. M. Mahler defined the period between 10-15 months of life as a phase of rehearsal in the process of individuation and described it as a time when a child experiences an affair with the world and his emerging skills. The theory of characterological development states that this is a particularly important stage in the acquisition of autonomy, primarily in terms of taking autonomous risk, initiative, self-determination and self-objectivity in action (Mahler et al., 2011).

Early and critical events that repel the desire for separation, initiative, and risk occur when parental signals indicate danger. This usually happens when guardians feel threatened by the child's "sets" in its autonomous functions and by 


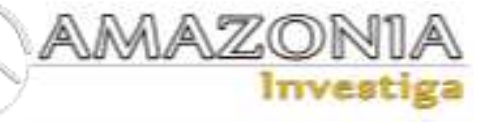

its early feelings of self, or when children's movements are actively punished because they are perceived as "unacceptable" or inconvenient. This leads to the emergence of such a false Self, in which - as with all such adaptations - identity is in contact with others, as opposed to a sense of identity that is acquired through the exercise of autonomous personality functions.

Autonomy is the central definition of transactional analysis, which is achieved by the disclosure or restoration of three abilities awareness, spontaneity and intimacy. Autonomous are behaviors, thoughts or feelings that are a reaction to the reality of the "here and now" and not to the scenario beliefs or demands of the Parent's ego-state (Berne, 1966).

Autonomous behavior is characterized by knowledge about oneself, the world and other people, spontaneous expression of authentic feelings and willingness to enter into open, based on respect for others, relationships. The closest connection with autonomy has a constant pattern of feelings and experiences, focused on taking into account the actual possibilities and autonomous action based on objective data - the Adult ego-state.

The essence of the ego-state model is that it allows you to establish a reliable connection between behavior, thoughts and feelings. If a person demonstrates a consistent set of behaviors that characterize the Child ego-state, then it is safe to assume that he also feels the experiences and emotions from his childhood. If a person changes his behavior and begins to reproduce the signals inherent in the Adult ego-state, then, accordingly, his thoughts and feelings are the thoughts and feelings of an adult who responds to the "here and now". If a person externally shows the behavior that he copied from his parents, he will internally reproduce the thoughts and feelings that he also borrowed from them.

According to F. Ruppert (2010), for a healthy mental development, a child needs symbiotic needs for warmth, protection, support, love and belonging to the family, which must be met. At the same time, the child's desire for autonomy must also be satisfied. Autonomy and pseudoautonomy have their own characteristics. Thus, autonomy is characterized by independence in relationships, acceptance of help if necessary, trust, and realistic self-esteem. At the opposite pole - pseudo-autonomy - isolation and immersion, fear of dependence, distrust as a basic feeling, overestimation of their own capabilities (Ruppert, 2010).
Note that a person is able to realize his shortcomings, the imperfection of relationships with others only at the appropriate level of development of the Self-concept: self-identity, autonomy, authenticity. Individuals with a wellestablished image of Self, with a high level of self-identity, autonomy, sovereignty have a high level of tolerance for novelty (information, views of other people, ways of action, behavioral strategies), i. e. easily perceive the variability of life and change themselves, develop, become independent (Blynova et al., 2020c; Khmiliar et al., 2020).

Untested image of Self, immature, diffuse identity causes anxiety, fear beyond one's independence, makes it difficult to adapt to changing social living conditions and prevents the development of independence of future professionals. In this case, the individual is in contact with the outside world through defense mechanisms. Fearing to lose Self, to dissolve, the individual blocks self-change, remains true to his stereotypes, habitual assessments and behaviors. And does not understand that life goes on, changes, takes new forms, and therefore, he does not simply "remain the same", he lags behind, "becomes obsolete", does not satisfy to modern, present life. Continuous development of independence is not a luxury, but an indispensable condition for personal survival - a condition for maintaining a balance between life and man (two trains go in the same direction, at the same speed, with no lag or overtaking). Otherwise, a person has a feeling: I do not understand life, it becomes different, I grow old, I do not get in the way. The result is a loss of control over the course of life, a loss of selfesteem, and a person desperately clings to the old system, his behavior becomes protective. If the mechanisms of psychological protection do not work, there is often immersion in the disease, various forms of escapism, neurosis (Hrys, 2015).

An important condition for the personal development of independence is a stable, wellestablished idea of the individual about himself (self-identity, autonomy, sovereignty), which will preserve the nucleus of the individual with changes in its husks, peripheral dispositions. Autonomization as a mechanism of individualization of personality in turn is realized through awareness, appropriation, rethinking, differentiation, internalization, creative realization and integration. O. Dergachova (2011) also defines personal autonomy as a psychological construct that describes a person's 
ability to be himself, to know what he wants and to be able to realize it.

Autonomization is a mechanism for an individual to defend his natural and human essence, the ability to distinguish him from the collective whole; to occupy a special position in society. Identification and autonomy are seen as dialectically related mechanisms: identification is the mechanism by which a subject experience his identification with the object of identification: another person or any object. Autonomization - the desire of the individual to stand out from others, the subject's experience of his alienation from the object. Objectively, identification acts as a mechanism of "appropriation" by the individual of his human essence, as a mechanism of the personal's socialization and autonomy - as a mechanism of the personal's individualization (Arbeláez-Campillo et al., 2018; Pinkovetskaia et al., 2020).

The assigned elements of the structure of selfconsciousness are filled with individual content and are fixed in the personality due to its ability to autonomy. Identification is also selective: external influences are always mediated by internal content, the position of the individual. The ability to autonomy - is primarily a positive ability to maintain, protect, and preserve the individual. The level of the second birth of the individual, associated with the formation of worldview. Manifestation of active will, through which the worldview is realized in society, is independence. And although this independence is learned through the examples of significant people with whom he identifies, independence necessarily requires the ability to autonomy. At this stage of personality development, the mechanism of autonomy operates at the emotional and cognitive levels, this makes it possible to "keep your face" not only on an emotional but also on a rational level when interacting with other people. Considering the hyperfunction of the mechanisms of personality identity, it should be noted that in the deprivation of personality the desired level of autonomy can be replaced by alienation, and insufficient level of autonomy and hyperfunction of identification can cause blurred identity, codependence of personality.

Researchers of the problems of codependent and anti-dependent behavior turn to deeper mechanisms of independence (Weinhold \& Weinhold, 2002). Codependent people usually develop a collapsed false Self, they look weak and helpless. And a person with anti-dependent behavior develops a bloated false Self. Individuals with codependent behavior are more prone to depression, and individuals with antidependent behavior are more prone to grandiosity so as not to feel depressed. To complete the process of psychological birth it is necessary to overcome the internal struggle between two "imaginary" opposing forces: a natural desire for fusion and intimacy and an equally strong desire for emotional separation and self-determination.

Once the psychological birth process is complete, there will be a deep sense of who the person really is, he will be able to cope with problems and conflicts, feeling a minimum of stress, maintaining the feeling that $\mathrm{He}$ and Others are good. Then it is possible to maintain the permanence of the object, dealing with most of life's problems. Under such conditions, the individual will be able to be both close and intimate and show separation when he wants.

Thus, the development of personal independence is provided by the need for change, improvement, openness to the new, including feedback, the ability to continuous self-analysis and mastery of new opportunities.

Despite the contradictions in the definition of terms, scientists agree on one thing: independence is the most important characteristic of the individual, without which he is not fullfledged. This is due to the organic connection of this phenomenon with the general course of physiological, psychological, socio-personal development of the child and its individual characteristics.

Thus, we can conclude that independence is a systemic quality of the subject, which has a unique content and structure, which is reflected in the activity. In studying the psychological content and structure of independence, we proceeded from the understanding that the manifestation of specific activity can be explained based on the properties of a holistic system, one of the components of which it serves. The above levels of the system, in this case, personal characteristics and relationships between them, which represent independence, will determine the specifics of its activity.

\section{Materials and methods}

The methodological starting points of our experiment in establishing the relationship of functional-role positions (ego-states) with indicators of independence of future 


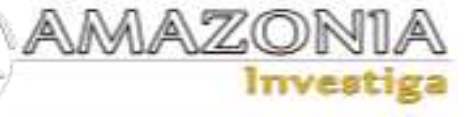

professionals are a sequence of actions combined into a research complex using psychodiagnostic techniques, which have been tested in a number of studies (Khmil \& Popovych, 2019; Halian et al., 2020b). In the selection of psychodiagnostic tools, we have taken into account a number of key requirements that have provided a relevant reflection of the subject of research (Shevchenko et al., 2020). This methodology has absorbed the best elements that have been introduced by researchers in the process of studying adaptation (Blynova et al., 2020a; 2020d; Kononenko et al., 2020), emotional intelligence (Cheban et al., 2020; Halian et al., 2020a), innovation (Marchuk \& Yatsyna 2020; Tsiuniak et al., 2020), as well as in the study of mental expectations in various activities of respondents (Blynova et al., 2020b; Chiţu, 2020; Griban et al., 2019; Nosov et al., 2020; Popovych et al., 2020; Prontenko et al., 2019a; 2019b; Shkola et al., 2019; Zinchenko et al., 2020). All these empirical sources are fully or partially relevant in the context of establishing the relationship of functional-role positions (egostates) with indicators of independence of future specialists in the training process.

Participants. Students of regional and metropolitan free economic zones of Ukraine, full-time and part-time education (Institution of higher education) took part in our research. In total - 787 students. Of these, 498 students were studied at the initial stage (using the method of content analysis in order to determine how modern students understand the meaning of the concept of "Independent Personality" and what factors determine the development of independence). Based on the received data, the author's methods of studying the independence of the future specialist were created.

At the next stage of the empirical part of the study, 289 students of Institution of higher education - Volodymyr Dahl East Ukrainian National University (Ukraine) (VDEUNU) took part - 46.4\%, Interregional Academy of Personnel Management (Ukraine) (IAPM) 24.6\%, Institute of Personnel Training of the State Employment Service of Ukraine (Ukraine) (IPTSESU) - 11.1\%, Odessa National Academy of Telecommunications n. a. O.S. Popov (Ukraine) (ONAT) $-18 \%$. Among the surveyed females $-86.9 \%$, males $-13.1 \%$, average age 21.6 years.

Distribution of students by courses of study: the first $-25.6 \%$, the second $-16.3 \%$, the third $20.8 \%$, the fourth $-6.6 \%$, the fifth $-21.8 \%$, the sixth $-9.0 \%$. The study involved students of the following specialties: Preschool education -
Psychology, Preschool education - Speech Therapy, Ecology and Tourism, Chemistry and Biology, Geography and Foreign Language, Chemistry, Foreign Language, Physics, Practical Psychology, Social Pedagogy. The information was provided by all respondents. The research is held according to the ethical standards of the committee on the rights of experiments of the Helsinki declaration (2013).

Instruments. Questionnaires and psychodiagnostic methods were used to organize the empirical study: Projective method "Composition", the results of which were analyzed by the method of content analysis (Raigorodsky, 2008). The methodology was used to find out what future specialists think about the phenomenon of independence, what are their basic ideas about the nature of this phenomenon, how they understand and interpret the process and result of the development of independence as a systemic personal quality, how they assess the level of formation of other character traits that constitute independence. And also, possible ways of development of independence in the conditions of higher educational institution.

All projective methods as well as the method "Composition" has average indicators of validity and reliability and are difficult to interpret. However, the "Composition" technique is extremely effective in relieving tension and selfcontrol. Therefore, together with other standardized methods and tests, the method "Composition" gives a reliable result. The purpose of this projective technique is to study the peculiarities of the perception of future specialists of independence as a personal quality. The Composition offered the following instructions: "Write a short essay on". How do I understand the concept of personality independence? Do I consider myself as an independent person? What personality traits are most associated with independence? Assess the level of your independence on a ten-point scale. 0 - completely non-independent, 10 - completely independent.

The received data were analyzed by content analysis. The main parameters of the analysis of these works were: understanding the nature of the independence of the individual as a psychological phenomenon; assessment of the level of formation of the student's own independence; character traits that help or hinder the development of independence.

Self-assessment of independence was carried out using the author's method "Indirect self- 
assessment of independence" ("ISI") (Hrys, 2015). The creation of the methodology was preceded by the collection of indirect indicators of independence, selection of the most frequent indicators, reducing the dimensionality of the semantic space of indicators of independence through exploratory factor analysis.

Personal beliefs about independence were measured using the author's questionnaire "Persuasion in independence" ("PII") (Hrys, 2015), which contains a number of statements about the nature of independence - acquired ("Independence is an acquired quality of personality"), "The development of independence is facilitated by the space of the university") or innate "Independence is an innate quality of personality", "Independent are those whose natural desire is the desire for emotional separation and self-determination"), and its role in life - constructive ("Psychologically prosperous individuals become independent", "Independence is influenced by the process and result of self-knowledge and self-improvement") or destructive ("Become independent to avoid punishment", "They become independent for fear of being rejected").

Methodology of C. Ryff (1989) "Scale of Psychological Well-being" ("SPW") (Ryff, 1989). Test "Influence on the position and motivation of the individual" to measure internal and external motivation ("IPM") and methods "Psychological boundaries of personality" ("PBP”) (Raigorodsky, 2008). Methodology "Anti-Independence" B. Weinhold and J. Weinhold (Weinhold \& Weinhold, 2002). Methodology "Codependence" B. Weinhold and J. Weinhold (Weinhold \& Weinhold, 2002).
Methodology of S. Schwartz "Portrait of values" ("PV") (Schwartz, 2010). Methodology J. Hay "Functional ego-states "Self" states" ("FES") (Hay, 2009).

Procedure. "The empirical research was hold during 2012-2018. The organizers of the study randomly selected young students who voluntarily agreed to participate in the empirical research. In advance, we received permission and advice from the administrations of higher education institutions. Each respondent filled in questionnaire forms and a questionnaire. Participation in the research was voluntary and confidential. Particular attention was paid to ensuring the confidentiality of the data received and avoiding accidental responses.

Data analysis. Statistical processing of the received results was carried out using the methods of mathematical statistics in the programs "Excel" and "SPSS" v. 17. These statistically significant differences were established by the criterion of sign ranks of Wilcoxon at $\mathrm{p} \leq .05$. Structural relationships in the psychological system of independence are established through the use of correlation analysis (Spearman's correlation coefficient, $r_{s}$ ).

\section{Results}

Research of features of functional-role positions (ego-states) of future specialists' independence.

To measure the internal role position, the "Functional ego-states "Self" states" ("FES") (Hay, 2009). The results of the diagnosis of the internal role position are reproduced in Tabl. 1 and Tabl. 2.

Table 1.

Diagnostic results according to the "FES"

\begin{tabular}{llll}
\hline Scale & $\mathbf{M}_{\text {emp }}$ & M & SD \\
\hline Parent-guardian & 14.09 & 14.38 & 3.19 \\
Free child & 14.18 & 13.81 & 3.19 \\
Adult & 13.55 & 13.11 & 3,97 \\
Adaptive child & 12.60 & 12,79 & 3,20 \\
Parent-controller & 9.66 & 10.27 & 4.08 \\
\hline
\end{tabular}

Note: $\mathrm{M}_{\mathrm{emp}}$ - empirical arithmetic mean; $\mathrm{M}$ - arithmetic mean; $\mathrm{SD}$ - mean-square deviation.

From the sample in general, ego-states "Parentguardian" (care and help to other people), "Free child" (expression of his feelings and actions without censorship and references to rules and requirements, intuition and authentic feelings), "Adult" (realism, freedom of choice, responsibility), have the highest rates and do not differ statistically significantly from each other.
Indicators on the scale "Adaptive child" (interaction with the rules and requirements of family and society, ways of manifestation obedience or rebellion) occupy an intermediate place - they are higher than the scale "Parentcontroller" (control, management, criticism of others) and lower for the indicators of the scales "Parent-guardian" and "Free child". The lowest 


\section{AMAZONDA \\ Invegtiga}

rate is in ego-state "Parent-controller". These statistically significant differences were established by the criterion of sign ranks of Wilcoxon at $\mathrm{p} \leq .05$.

Functional role position (ego-state "Adult"). The highest rates of students have the following ego-

Table 2.

The level of manifestation of functional ego-states according to the "FES"

\begin{tabular}{llll}
\hline \multirow{2}{*}{ Scale } & \multicolumn{2}{l}{ Level of manifestation } & \\
\cline { 2 - 4 } & Low & Medium & High \\
Parent-guardian & 22.0 & 62.7 & 15.3 \\
Free child & 13.6 & 72.9 & 13.6 \\
Adult & 18.6 & 69.5 & 11.9 \\
Adaptive child & 13.6 & 72.9 & 13.6 \\
Parent-controller & 15.3 & 67.8 & 16.9 \\
\hline
\end{tabular}

The distribution of levels of functional ego-states is statistically the same (at $\mathrm{p} \leq .05$ ), at the same time, there is a tendency to statistically significant differences for the low level - the number of students on the scale "Parentguardian" is greater than on the scales "Free child" and "Adaptive child" $\mathrm{NF}=1.21(\mathrm{p} \leq .1)$. states: "Parent-guardian" (care and help to other people), "Free child" (expression of his feelings and actions without censorship and references to rules and requirements), "Adult" (realism, freedom of choice, responsibility).

Table 3

Correlation relationships of indicators according to the "FES" with indicators of other methods $\left(\mathrm{r}_{\mathrm{s}}\right)$

\begin{tabular}{|c|c|c|c|c|c|}
\hline Scale & 竘离 & 窇总 & $\frac{5}{E}$ & 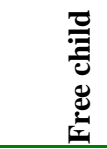 & 斑 \\
\hline Positive Relationships (“SPW") & -.111 & $-.266^{1}$ & .122 & -.082 & .012 \\
\hline Self-acceptance (“SPW”) & $-.301 *$ & -.195 & -.152 & -.130 & -.050 \\
\hline Psychological well-being (“SPW") & -.136 & $-.263^{1}$ & .010 & -.004 & .007 \\
\hline $\begin{array}{l}\text { Conformism ("PV") } \\
\text { Tradition ("PV") } \\
\text { Universalism ("PV") } \\
\text { Independence ("PV") } \\
\text { Achievements ("PV") } \\
\text { Power ("PV") } \\
\text { Openness ("PV") } \\
\text { Conservatism ("PV") } \\
\text { Self-transcendence ("PV") } \\
\text { Self-affirmation ("PV") } \\
\text { External motivation ("IPM") }\end{array}$ & $\begin{array}{l}.089 \\
-.242^{1} \\
.015 \\
.301^{*} \\
.309^{*} \\
.500^{* *} \\
.229^{1} \\
-.052 \\
.013 \\
.357 * * \\
-.038\end{array}$ & $\begin{array}{l}.211 \\
.215^{1} \\
.203 \\
.135 \\
-.036 \\
-.049 \\
.153 \\
.218^{1} \\
.218^{1} \\
-.008 \\
.095\end{array}$ & $\begin{array}{l}.081 \\
-.058 \\
.216^{1} \\
.345^{* *} \\
.006 \\
.124 \\
.209 \\
.049 \\
.197 \\
.040 \\
.192\end{array}$ & $\begin{array}{l}.270^{*} \\
-.165 \\
-.097 \\
-.000 \\
-.031 \\
.114 \\
-.094 \\
.072 \\
-.132 \\
.005 \\
.270^{*}\end{array}$ & $\begin{array}{l}.019 \\
-.008 \\
-.128 \\
-.168 \\
-.115 \\
-.119 \\
-.2241 \\
-.073 \\
-.119 \\
-.139 \\
.099\end{array}$ \\
\hline $\begin{array}{l}\text { Internal motivation ("IPM") } \\
\text { Anti-Dependence ("AD") } \\
\text { Codependence ("CD") } \\
\text { Innate independence ("PSS") }\end{array}$ & $\begin{array}{l}.154 \\
.261 * \\
.033 \\
.177\end{array}$ & $\begin{array}{l}.215^{1} \\
.317^{*} \\
.337^{*} \\
.242^{1}\end{array}$ & $\begin{array}{l}.135 \\
-.124 \\
.065 \\
.096\end{array}$ & $\begin{array}{l}-.061^{1} \\
.226^{1} \\
-.027 \\
.090\end{array}$ & $\begin{array}{l}-.151 \\
.057 \\
.233^{1} \\
.056\end{array}$ \\
\hline Acquired independence ("PSS") & $.226^{1}$ & .196 & .133 & .203 & .121 \\
\hline Destructive independence (“PSS") & -.001 & $.221^{1}$ & .041 & .176 & .096 \\
\hline Fully permeable limit ("PBP”) & .189 & $.287 *$ & .212 & -.087 & .116 \\
\hline $\begin{array}{l}\text { Assimilation limit ("PBP") } \\
\text { Restraint limit ("PBP") }\end{array}$ & $\begin{array}{l}.325^{*} \\
-.036\end{array}$ & $\begin{array}{l}.075 \\
.033\end{array}$ & $\begin{array}{l}.097 \\
.095\end{array}$ & $\begin{array}{l}-.111 \\
-.231^{1}\end{array}$ & $\begin{array}{l}-.057 \\
-.061\end{array}$ \\
\hline
\end{tabular}

Note: ${ }^{1}-(\mathrm{p} \leq .1) ;{ }^{*}-(\mathrm{p} \leq .05) ;{ }^{* *}-(\mathrm{p} \leq .01)$

Research of relationships of functional-role positions (ego-states) with indicators of future specialists' independence.

Let's analyze the relationship of indicators according to the J. Hay questionnaire "Functional ego-states" ("FES") with indicators of other methods (see Tabl. 3). 
The indicator of the scale "Adult" ("FES") is positively correlated with the indicators of the scales "Universalism" $\left(\mathrm{r}_{\mathrm{s}}=.216 ; \mathrm{p} \leq .1\right)$ and "Independence" $\left(\mathrm{r}_{\mathrm{s}}=.345 ; \mathrm{p} \leq .01\right)$ of the method of S. Schwartz (2010) ("PV"). The more students are focused on taking into account the actual possibilities and autonomous action based on objective data (the Adult ego-state), the more they prone to independence of thought and action, choice, creativity (value "Independence"), as well as understanding, tolerance, protection of the well-being of all people and nature (the value of "Universalism").

The indicator of the scale "Parent-controller" ("FES") is positively correlated with the indicators of the scales "Independence" $\left(\mathrm{r}_{\mathrm{s}}=.301\right.$; $\mathrm{p} \leq .05)$, “Achievements" $\quad\left(\mathrm{r}_{\mathrm{s}}=.309 ; \mathrm{p} \leq .05\right)$, "Power" ( $\left.\mathrm{r}_{\mathrm{s}}=.500 ; \mathrm{p} \leq .01\right)$, "Openness" $\left(\mathrm{r}_{\mathrm{s}}=.229\right.$; $\mathrm{p} \leq .1)$, "Self-affirmation" $\left(\mathrm{r}_{\mathrm{s}}=.357 ; \mathrm{p} \leq .01\right)$ of the method of S. Schwartz (2010) ("PV"), "Antidependence" ("AD") $\left(\mathrm{r}_{\mathrm{s}}=.261 ; \mathrm{p} \leq .05\right)$, "Acquired independence" ("PBP") $\quad\left(\mathrm{r}_{\mathrm{s}}=.226 ; \mathrm{p} \leq .1\right)$, "Assimilative limit" ("PBP") $\left(\mathrm{r}_{\mathrm{s}}=.325 ; \mathrm{p} \leq .05\right)$ and significantly negatively correlates with the indicators of the scales "Self-acceptance" ("SPW") $\left(\mathrm{r}_{\mathrm{s}}=-.301 ; \mathrm{p} \leq .05\right)$ and "Tradition" ("PV") $\left(\mathrm{r}_{\mathrm{s}}=-.242 ; \mathrm{p} \leq .1\right)$.

The indicator of the scale "Parent-guardian" ("FES") significantly correlates positively with the indicators of the scales "Tradition" $\left(\mathrm{r}_{\mathrm{s}}=.215\right.$; $\mathrm{p} \leq .1)$, "Conservatism" $\left(\mathrm{r}_{\mathrm{s}}=.218 ; \mathrm{p} \leq .1\right)$, "Selftranscendence" $\left(r_{s}=.218 ; p \leq .1\right)$ of the method of S. Schwartz ("PV"), "Internal Motivation" ("IPM") $\quad\left(\mathrm{r}_{\mathrm{s}}=.215 ; \mathrm{p} \leq .1\right)$, "Anti-dependence" ("AD") $\quad\left(\mathrm{r}_{\mathrm{s}}=.317 ; \quad \mathrm{p} \leq .05\right), \quad$ "Codependence" ("CD") $\left(\mathrm{r}_{\mathrm{s}}=.377 ; \mathrm{p} \leq .05\right)$, "Innate Independence" ("PPS") $\quad\left(\mathrm{r}_{\mathrm{s}}=.242 ; \quad \mathrm{p} \leq .1\right), \quad$ "Destructive Independence" ("PSS") $\quad\left(\mathrm{r}_{\mathrm{s}}=.221 ; \mathrm{p} \leq .1\right)$, "Completely permeable limit" ("PBP") and significantly negatively correlates with the indicator of the general score of the method of C. Ryff (1989) ("SHPB") and its scale "Positive Relations" ( $\left.\mathrm{r}_{\mathrm{s}}=-.266 ; \mathrm{p} \leq .1\right)$.

The indicator of the scale "Free Child" ("FES") significantly correlates positively with the indicators of the scales "Conformism" $\left(\mathrm{r}_{\mathrm{s}}=.270\right.$; $\mathrm{p} \leq .05)$ of the method of S. Schwartz (2010) ("PV"), "External motivation" ("IPM") $\left(\mathrm{r}_{\mathrm{s}}=-\right.$ $.061 ; \mathrm{p} \leq .1), \quad$ "Anti-Dependence" ("AD”) $\left(\mathrm{r}_{\mathrm{s}}=.226 ; \mathrm{p} \leq .1\right)$ and significantly negatively correlates with the indicator of the scale "Restraint limit" ("PBP") $\left(\mathrm{r}_{\mathrm{s}}=-.231 ; \mathrm{p} \leq .1\right)$.

The indicator of the scale "Adaptive child" ("FES") significantly correlates positively with the indicators of the scale "Codependence"
("CD") $\quad\left(\mathrm{r}_{\mathrm{s}}=.233 ; \quad \mathrm{p} \leq .1\right) \quad$ and significantly negatively correlates with the indicator of the scale "Openness" $\left(\mathrm{r}_{\mathrm{s}}=-.224 ; \mathrm{p} \leq .1\right)$ of the method of S. Schwartz (2010) ("PV").

\section{Conclusions}

1) The essence of the phenomenon of independence as a systemic quality of the personality of the future specialist is revealed, which is based on autonomous behavior, which is characterized by knowledge about oneself, the world and other people. It is characterized by a spontaneous manifestation of authentic feelings and a willingness to enter into open relationships, based on respect for others. The closest connection with autonomy has a constant pattern of feelings and experiences, focused on taking into account the actual possibilities and autonomous action based on objective data - the ego-state "Adult" (Adult ego-state).

2) It is noted that the system of independence is determined, on the one hand, by the internal organization and the relationship of structural components, and on the other hand, the fact that independence in determining the level of subjectivity is realized in the specific activity of the subject. Thus, independence performs a system-forming function for the subject as a system.

3) Autonomous behavior is characterized by knowledge about oneself, the world and other people, spontaneous expression of authentic feelings and willingness to enter into open relationships. The closest connection with autonomy has a constant pattern of feelings and experiences, focused on taking into account the actual possibilities and autonomous action based on objective data - the ego-state "Adult" (Adult egostate).

4) It was found that the more important for respondents the value of independence, the more they are focused on taking into account the actual possibilities and autonomous action based on objective data (ego-state "Adult"), as well as control, management, criticism of other people (ego-state "Parentcontroller").

5) The more autonomous students, the less interdependent they are, and vice versa. Codependence and anti-dependence are significantly positive. The higher the rates of anti-dependence, the more students are prone to control, management, criticism of other people ("Parent-controller") and at the 
same time, to care for and help other people ("Parent-Guardian"). The higher the rates of codependence, the more students are inclined to care for and help other people ("Parent-Guardian"). The more students are willing to trust others, to identify with them (a completely perceptible boundary), the more they are willing to care for and help other people ("Parent-Guardian"). The functional ego-states "Parent-Controller", "Parent-Guardian", "Adult" are all significantly positively related.

6) Our hypotheses are confirmed, the received data are important for an objective understanding of the psychological mechanisms of formation of the independence of the future specialist; the acquired knowledge should be used in the preparation of targeted programs for the development of independence as a systemic quality of personality.

\section{References}

Arbeláez-Campillo, D., Rojas-Bahamón, M.J., \& Arbeláez-Encarnación, T. (2018). Apuntes para el debate de las categorías ciudadanía universal, derechos humanos y globalización. Notes for the debate of the categories universal citizenship, human rights and globalization. Cuestiones Políticas, 34(61), 139-160.

Berne, E. (1966). Principles of Group Treatment. New York: Oxford University Press. https://www.pdfdrive.com/eric-berne-

_principles-of-group-treatment-d41272633.html Blynova, O., Chervinska, I., Kazibekova, V., Bokshan, H., Yakovleva, S., Zaverukha, O., \& Popovych, I. (2020a). Social and Psychological Manifestations of Professional Identity Crisis of Labor Migrants. Revista Inclusiones, 7(3), 93-105.

http://www.revistainclusiones.org/index.php/inc lu/article/view/1318

Blynova, O., Lappo, V., Kalenchuk, V., Agarkov, O., Shramko, I., Lymarenko, L., \& Popovych, I. (2020b). Corporate Culture of a Higher Education Institution as a Factor in Forming Students' Professional Identity. Revista Inclusiones, 7(Especial), 481-496. http://www.revistainclusiones.org/index.php/inc lu/article/view/1305

Blynova, O., Popovych, I., Semenova, N., Kashyrina, Ye., Ursulenko, O., \& Kononenko, O. (2020c). Personality Factors of Choosing Adaptation Strategies in a Different Cultural Environment by Labor Migrants from Ukraine. Revista Amazonia Investiga, 9(32), 45-54. Retrieved from http://dx.doi.org/10.34069/AI/2020.32.08.5
Blynova, O., Moiseienko, V., Los, O., Burlakova, I., Yevdokimova, O., Toba, M., \& Popovych, I. (2020d). Assertiveness as a Factor of Students' Choice of Behavior Strategies in Social Interaction. Revista Inclusiones, 7(4), 259-272.

http://www.revistainclusiones.org/index.php/inc lu/article/view/1551

Cheban, Yu. V., Chebykin, O. Ya., Plokhikh, V. V., \& Massanov, A. V. (2020). Emotional factor of competitive selfmobilization of professional rowers". Insight: the psychological dimensions of society, 3, 28-43. https://doi.org/10.32999/2663-970X/2020-3-2

Chiţu, E. (2020). The Importance of Employer Branding in Recruiting Young Talents. Postmodern Openings, 11(3), 220-230. https://doi.org/10.18662/po/11.3/209

Dergachova, O. E. (2011). Personality autonomy as constituent of personality potential. In: Dergachova, O. E., \& Leontiev, D. A. Personality potential: structure and diagnostics. Moscow: Sense. https://istina.msu.ru/publications/article/124476 1/

Griban, G., Prontenko, K., Yavorska, T., Bezpaliy, S., Bublei, T., Marushchak, M., Pustoliakova, L., Andreychuk, V., Tkachenko, P., Zhukovskyi, Ye., Baldetskiy, A., \& Bloshchynskyi, I. (2019). Non-traditional means of physical training in middle school physical education classes. International Journal of Applied Exercise Physiology, 8(3.1), 224-32. DOI: 10.26655/IJAEP.2019.10.1

Halian, A., Halian, I., Burlakova, I., Shevchenko, R., Lappo, V., Zhigarenko, I., \& Popovych, I. (2020a). Emotional Intelligence in the Structure of Adaptation Process of Future Healthcare Professionals". Revista Inclusiones, 7(3), 447460.

http://www.revistainclusiones.org/index.php/inc lu/article/view/1347

Halian, I., Machynska, N., Lozynska, S., Nos, L., Derkach, Yu., Prots, M., \& Popovych, I. (2020b). Tolerance of uncertainty as a component of the process of life-creation of future educators. Revista Inclusiones, 7(Especial), 512-528. http://www.revistainclusiones.org/index.php/inc lu/article/view/1307

Halian, I. M. (2019). Personal determinants of responsibility of future educators. Insight: the psychological dimensions of society, 1, 15-21. https://doi.org/10.32999/2663-970X/2019-1-2

Hrys, A. (2015). Person's self-image and psychological limits in the context of adaptive processes. Kyiv.

Hay, J. (2009). Transactional analysis for trainers. Hertford: Sherwood Publishing. 
Khmiliar, O., Popovych, I., Hrys, A. et al. (2020). Spatial Regulation of Personality Behavior in the Conditions of Progression of the COVID-19 Pandemic. Revista Inclusiones, 7(Especial), 289-306. http://www.revistainclusiones.org/index.php/inc lu/article/view/1760

Khmil, V. V., \& Popovych, I. S. (2019). Philosophical and Psychological Dimensions of Social Expectations of Personality. Anthropological Measurements of Philosophical Research, 16, 55-65. https://doi.org/10.15802/ampr.v0i16.187540

Kononenko, O., Kononenko, A., Stynska, V., Kachmar, O., Prokopiv, L., Katolyk, H., \& Popovych, I. (2020). Research of the factor structure of the model of world view settings at a young age. Revista Inclusiones, 7(3), 98-116. http://www.revistainclusiones.org/index.php/inc lu/article/view/1618

Mahler, M., Payn, F., \& Bergman, A. (2011). Psychological birth of human baby: symbiosis and individuation. Moscow, Kogito. http://psychoanalysis.by/wp-

content/uploads/2018/03/symbiosis_individuati on.pdf?189db0\&189db0

Marchuk, L., \& Yatsyna, O. (2020). Practices of Informal Education as a Resource for SelfRealization of Self-Referential Identities in a Pandemic and Post-Pandemic Period. Postmodern Openings, 11(2), 99- 104. https://doi.org/10.18662/po/11.2/162

Nosov, P. S., Zinchenko, S. M. Popovych, I. S. Ben, A. P., Nahrybelnyi, Y. A., \& Mateichuk, V. M. (2020). Diagnostic system of perception of navigation danger when implementation complicated maneuvers. Electronics, Computer Science, Control, 1, 146161. DOI: 10.15588/1607-3274-2020-1-15

Passov, E. I. (2002). Culture-like model of professional preparation of teacher: philosophy, maintenance, realization. Foreign languages, 4, 3-18.

http://catalog.library.tnpu.edu.ua:8080/library/D ocDescription?doc_id=61858

Pinkovetskaia, I., Arbeláez-Campillo, D., Rojas-Bahamón, M., \& Veas Iniesta, D. (2020). Motivation of new entrepreneurs in modern economies. Amazonia Investiga, 9(29), 368-373. https://doi.org/10.34069/AI/2020.29.05.41

Popovych, I., Zhigarenko, I., Losiyevska, O., Dovbenko, S., Kashyrina, Ye., Shevchenko, R., \& Piletska, L. (2020). Research of Achievement Motivation's Impaction the Career Orientations of Future Managers of Organization. Revista Inclusiones, 7(Especial), 247-263. http://www.revistainclusiones.org/index.php/inc lu/article/view/1231
Prontenko, K., Griban, G., Tymoshenko, O., Bezpaliy, S., Kalynovskyi, B., Kulyk, T., Prontenko, V., Domina, Zh., Tkachenko, P., Kozenko, S., Andreychuk, V., \& Bloshchynskyi, I. (2019a). Methodical system of kettlebell lifting training of cadets during their physical education. International Journal of Applied Exercise Physiology, 8(3.1), 240-248. DOI: 10.26655/IJAEP.2019.10.1.

Prontenko, K., Griban, G., Bloshchynskyi, I., Boyko, D., Loiko, O., Andreychuk, V., Novitska, I., \& Tkachenko, P. (2019b). Development of power qualities of cadets of Ukrainian higher military educational institutions during kettlebell lifting training. Baltic Journal of Health and Physical Activity, 11(3), 27-38. DOI: 10.29359/BJHPA.11.3.04.

Raigorodsky, D. Ya. (2008). Encyclopedia of Psychodiagnostics. Psychodiagnostics of children. Samara: Bahrakh-M.

Rubinstein, S. L. (2007). Bases of general psychology. St. Petersburg: Peter. http://yanko.lib.ru/books/psycho/rubinshteyn=os novu_obzhey_psc.pdf

Ruppert, F. (2010). Trauma, connection and domestic placing. To understand and cure spiritual wounds. Moscow: Institute of advising and system decisions. https://www.studmed.ru/ruppert-franc-travmasvyaz-i-semeynye-rasstanovki-ponyat-i-iscelitdushevnye-rany_aba97fdd0a6.html

Ryff, C. D. (1989). Happiness is everything, or is it? Explorations on the meaning of psychological well-being. Journal of Personality and Social Psychology, 57(6), 1069-1081. https://doi.org/10.1037/0022-3514.57.6.1069

Schwartz, S. H. (2010). Basic values: How they motivate and inhibit prosocial behavior. In M. Mikulincer \& P. R. Shaver (Eds.), Prosocial motives, emotions, and behavior: The better angels of our nature (p. 221-241). American Psychological Association. https://doi.org/10.1037/12061-012

Shevchenko, R., Popovych, I., Spytska, L., Nosov, P., Zinchenko, S., Mateichuk, V., \& Blynova, O. (2020). Comparative analysis of emotional personality traits of the students of maritime science majors caused by long-term staying at sea. Revista Inclusiones, 7(Especial), 538-554.

http://www.revistainclusiones.org/index.php/inc lu/article/view/1309

Shkola, O., Griban, G., Prontenko, K., Fomenko, O., Zhamardiy, V., Bondarenko, V., Bezpaliy, S., Andreychuk, V., Tkachenko, P., Zhukovskyi, Ye., Novitska, I., \& Bloshchynskyi, I. (2019). Formation of valuable orientations in youth during physical training. International 
Journal of Applied Exercise Physiology, 8(3.1), 264-272. DOI: 10.26655/IJAEP.2019.10.1

Tsiuniak, O., Pyslar, A., Lialiuk, G., Bondarenko, V., Kovtun, O., Los, O., \& Popovych, I. (2020). Research of interdependence of variables and factor structure of masters' readiness for innovative pedagogical activity. Revista Inclusiones, 7(3), 427-452. http://www.revistainclusiones.org/index.php/inc lu/article/view/1645

Weinhold, B., \& Weinhold, J. (2002). Breaking Free of the Codependence. Moscow: Class. https://www.twirpx.com/file/238614/
World Medical Association Declaration of Helsinki. (2013). Ethical principles for medical research involving human subjects, 310(20), 2191-4.

https://doi.org/10.1001/jama.2013.281053

Zinchenko, S. M., Ben, A. P., Nosov, P. S., Popovych, I. S., Mamenko, P. P., \& Mateychuk, V. M. (2020). Improving the accuracy and reliability of automatic vessel moution control systems. Radio Electronics, Computer Science, Control, 2, 183-195. DOI: 10.15588/1607-3274-2020-2-19 